\title{
The Effect of Strengthened Monitoring and Oversight Mechanisms on U.S. Firms Listed on NASDAQ
}

\author{
Dishant Pandya, DBA \\ Assistant Professor of Finance, School of Business, Spalding University \\ 901 South Fourth Street, Louisville, Kentucky, 40203, Unites States \\ E-mail: dpandya@spalding.edu \\ Ian A. Van Deventer, CPA, PhD* \\ Assistant Professor of Accounting, School of Business, Spalding University \\ 901 South Fourth Street, Louisville, Kentucky, 40203, United States \\ E-mail: ivandeventer@spalding.edu
}

\begin{abstract}
Acknowledgement: We thank Dr. Wei Wang for sharing the data used in this study.
Abstract

Agency theory and conventional wisdom suggest that strengthened monitoring and oversight mechanisms are necessary to align the actions of management with the interests of shareholders, which should be to maximize shareholder wealth. In 2003, legislators and regulators strengthened corporate governance with a series of laws and regulations in response to a number of corporate scandals in the late 1990s. The purpose of this study is to determine how strengthened monitoring and oversight mechanisms affected the performance of U.S. companies listed with NASDAQ. In conjunction with the agency view and conventional wisdom, we expect strengthened corporate governance to reduce agency problems and costs and increase firm performance. We conducted the study with a sample of 381 firms and 5,005 firm-year observations from U.S. companies trading on NASDAQ over the period 1997-2012. We analyzed the data using a difference-in-difference methodology and found that most firms were not affected by the 2003 changes to NASDAQ rules. The results are consistent with the window-dressing view that suggests managers retained their influence over the board and appointed directors who technically met the new requirements but were sympathetic to management, giving the impression that changes were made.
\end{abstract}

Keywords: agency view; corporate governance; firm performance; monitoring; oversight; NASDAQ; difference-in-difference methodology; window-dressing view

DOI: $10.7176 /$ RJFA/12-16-02

Publication date:August $31^{\text {st }} 2021$

\section{Introduction}

Modern corporations are typically owned by many different shareholders who need knowledgeable and skilled individuals to act as agents and make business decisions on their behalf (Jensen \& Meckling, 1976). The hope is that agents will work in the best interests of shareholders to maximize returns on their collective capital investments (Agarwal, Goel, \& Vashishtha, 2014). As noted by Adam Smith in the late 1700s, the inherent problem with this expectation is that individuals tend to act in their own self-interests (Zogning, 2017). This creates a conflict between shareholders and their agents.

Conventional wisdom suggests the best way to motivate managers to work in the best interests of shareholders is to monitor them (Fama \& Jensen, 1983). Since the 1950s, legislators and regulators in the U.S. have steadily strengthened corporate-oversight mechanisms (Gordon, 2007). In response to corporate scandals of the late 1990s, such as Enron, Tyco, and WorldCom, legislators passed a set of laws collectively known as the Sarbanes-Oxley Act (SOX) in 2002 to strengthen financial-reporting and internal-control requirements. The U.S. Securities and Exchange Commission (SEC) also adopted a series of changes to corporate-governance rules for publicly traded firms introduced by the National Association of Securities Dealers Automated Quotations System (NASDAQ). Under these rules, the monitoring and oversight responsibilities of the board of directors were strengthened.

Historically, legislators and regulators sided with agency theorists who asserted that the best way to mitigate agency problems was to strengthen corporate governance (Fama \& Jensen, 1983; Gordon, 2007). Consistent with agency theory and conventional wisdom, we believe strengthened monitoring and oversight mechanisms are the key to reducing agency costs and, thereby, increasing firm performance. We believe a longterm view is needed to better understand how firm performance was affected by the 2003 SEC rules. We predict that these rules significantly and positively impacted the long-term performance of U.S. firms listed on NASDAQ

We analyzed data from 381 U.S. firms listed on NASDAQ and 5,005 firm-year observations using a difference-in-difference model. We used both accounting-based return (operating return on assets) as well as 
market-based return (Tobin's Q) to measure firm performance. The results of our study indicated that there was no significant change in long run firm performance of publicly traded firms listed on NASDAQ, meaning that U.S. firms were largely unaffected by the strengthened corporate-governance mechanisms.

There is currently very little research that investigates the effect of the 2003 changes in corporategovernance rules on the long-run performance of NASDAQ firms in the United States. Prior researchers studied only 1-4 years of post-regulation data. We were the first to analyze 10 years of financial data from NASDAQ firms in order to produce a clearer picture of the effect of the strengthened monitoring and oversight rules.

\section{Literature Review}

We highlight the evolution of the agency view as the dominant explanation of the relationship between shareholders and managers. We argue for mitigating agency problems using conventional wisdom. Lastly, we develop a research hypothesis from the current body of literature pertaining to strengthened corporate governance.

\subsection{Agency Theory}

The origin of agency theory has been traced back to Adam Smith, a philosopher who first published his views in 1776 (Zogning, 2017). He was the first to propose that managers are driven to peruse their own best interests and would likely put themselves ahead of their shareholders (Smith, 1776, as cited in Zogning, 2017). Agency theory was further developed by Ross (1973) and Mitnick (1973) who explained that problems arise as a result of conflicts between shareholders and managers (Mitnick, 2019). Jensen and Meckling (1976) further expanded agency theory with the idea that agency problems become agency costs when managers use their decisionmaking power to consume company resources for their own benefit.

In the modern corporate structure, managers derive their powers, in part, from their ability to influence the board of directors (who represent the interests of shareholders). Entrenched managers are firmly fixed in their positions and are difficult to remove because they have the ardent support of board members over whom they hold considerable influence (Bebchuk \& Fried, 2005). These managers essentially control their compensation packages and can make investment decisions that favor their personal portfolios rather than the interests of shareholders. Agency theorists believe that entrenched managers hinder the growth of firms to such an extent that decreasing agency problems will result in increased firm performance.

\subsection{Strengthened Corporate Governance}

In response to public outrage over a series of accounting scandals that included Enron, Tyco, and WorldCom in the late 1990s, regulators passed the Sarbanes-Oxley Act (SOX) in 2002. SOX established that management must 1) personally certify financial reports, 2) meet enhanced transaction and internal-control disclosure requirements, and that 3) audit committees have broadened responsibilities (Chhaochharia \& Grinstein, 2007; Pandya \& Van Deventer, 2021). These laws were passed by the U.S. Congress to strengthen corporate governance and to restore confidence in public accounting firms.

In 2003, shortly after SOX was passed, the Securities and Exchange Commission adopted additional changes to corporate-governance guidelines for public companies that traded on NASDAQ. The SEC established that firms must have 1) a majority of independent directors on the board, 2) independent directors meet a strict definition for independence, 3) independent directors meet regularly without the presence of others, 4) audit committees comprised of only independent directors, and that 5) nominating and compensation committees involve independent directors but need not be entirely independent (Chhaochharia \& Grinstein, 2007). These rules were approved by the Securities and Exchange Commission (SEC) in 2003 to restore investor confidence in in the stock market (Bhagat \& Bolton, 2008).

A number of studies were conducted to determine whether the SOX and NASDAQ changes in corporate governance impacted firm performance. Coles, Daniel, and Naveen (2008) studied data from the period 19922001 and found mixed results. The researchers indicated that some firms benefited from the strengthened corporate-governance rules and some firms were hindered by them. Duchin, Matsusaka, and Ozbas (2010) and Linck, Netter, and Yang (2008) produced similar results to Coles et al. (2008) using data from the period 19902004. Cheng (2008) collected data from the period 1996-2004 and produced mixed results similar to Coles et al. (2008), Duchin et al. (2010), and Linck et al. (2008). It is interesting to note that Coles et al. (2008) did not use post-regulation data in their study and came to a similar conclusion as Duchin et al. (2010), Linck et al. (2008), and Cheng (2008) who used only one year of post regulation data in their studies.

Faleye, Hoitash, and Hoitash (2011) and Chen, Cheng, and Wang (2011) used data from the period 19982006 and also produced mixed results, but they were the first researchers to use several years of post-regulation data (2004-2006) in their study. The researchers asserted that the new corporate-governance rules imposed by NASDAQ strengthened the monitoring function of the board at the expense of the advising function. The effect of this change was positive or negative depending on the monitoring or strategic advising needs of the firm. 
Wang, Xie, and Zhu (2015) looked at data from the period 2000-2007 and also had mixed results. In contrast to the rest of the post-regulation literature, Pandya and Bathala (2013) studied data from the period 2001-2006 but found no effect of the strengthened corporate-governance rules on firm performance.

Some of the earlier studies were flawed because they did not include enough post-regulation data. Other studies produced mixed results over a short period of three or four post-regulation years. We are the first to investigate post-regulation data for NASDAQ firms over an extended ten-year period, creating a clearer picture of the effect of the strengthened rules on firm performance.

\subsection{Hypothesis}

To combat agency problems, experts recommend strengthening corporate-governance mechanisms (Zogning, 2017). In the past, legislators and regulators have incrementally increased the monitoring responsibilities of the board of directors, becoming the conventional wisdom for dealing with agency problems since the 1950s (Gordon, 2007). In recent history, legislators passed the Sarbanes-Oxley Act of 2002, which chiefly impacted financial reporting and internal control requirements for managers (Chhaochharia \& Grinstein, 2007). In 2003, regulators with the SEC adopted new rules for publicly traded firms listed on NASDAQ. These measures impacted compensation and monitoring of management (Chhaochharia \& Grinstein, 2007). Following the historical trend and conventional wisdom, we predict that the strengthened corporate-governance rules will have a positive and significant effect on firm performance over an extended period of time.

$\mathrm{H}_{1}$ : Strengthened corporate-governance rules have a positive long-run effect on firm performance for firms listed on NASDAQ.

\section{Research Method}

We used the difference-in-difference (DD) estimation method to approximate the results of an exogenous shock by comparing the performance of insider-controlled firms (the control group) with outsider-controlled firms (the treatment group). The following equation represents the hypothesis:

Performance $_{i t}=\beta_{0}+\beta_{1}\left(\right.$ Inside Board $_{i} *$ Post Regulation $\left._{t}\right)+\Gamma X_{i t}+\delta_{i}+\Upsilon_{t}+\varepsilon_{i t}$.

We used operating return on assets (OROA) to measure firm performance, the primary dependent variable, and calculated it as the ratio of operating income before depreciation to total assets similar to Hermalin and Weisbach (1991), Bhagat and Black (2002), Bhagat and Bolton (2008), and Pandya and Van Deventer (2021). As an alternative measure of firm performance, we used the market-based return of Tobin's Q.

We proxy firms not in compliance with the proposed NASDAQ rules as those that did not have a majority of independent directors on the board at the end of fiscal year 2000 (Guo, Lach, \& Mobbs, 2015). We defined Inside Board as firms listed on NASDAQ that had a majority of inside directors in the year 2000. We coded Inside Board as 0 if the ratio of outside directors to the total number of directors on the board was greater than 0.5 and coded it as 1 if the ratio was equal to or less than 0.5 in the year 2000 .

Changes to the corporate-governance rules took effect in 2003, but the changes were announced in 2002 and some firms preemptively adopted the rules in 2002. For this reason, 2002 was selected as the year in which the mandated changes took effect. We coded Post Regulation equal to 1 for the year 2002 and beyond. The coefficient of the interaction variable Inside Board * Post Regulation, $\beta 1$, is the primary variable of interest. The interaction term measures the effect of the 2003 guidelines on firm performance of insider-controlled firms listed on NASDAQ. If management is entrenched, strengthened corporate-governance guidelines should benefit firms that make the required changes.

$X$ represents control variables used to restore randomness. Book Leverage Ratio represents the firm's total long-term debt. Market-to-Book Ratio represents the company's growth opportunities. Total Assets represents the size of the firm. We used the natural log version of these variables. Delta $(\delta)$ indicates firm fixed effects, Upsilon $(Y)$ indicates year fixed effects. The coefficients for Inside Board and Post Regulation were absorbed by firm and year fixed effects, respectively. The constant $(\beta 0)$ was suppressed to avoid the dummy variable trap, and epsilon is the error term. All firm-specific variables were winsorized at the top and bottom percentiles.

\section{Results and Discussion}

The data for this study were extracted from two sources. Information regarding the board of directors came from Institutional Shareholder Services (ISS; formerly RiskMetrics), which tracked the record of the S\&P 1500 firms in the period 1996-2009 and was matched with financial information provided by CompuStat for 1997-2012. This study includes only publicly traded U.S. companies listed on NASDAQ. 
4.1 Sample Statistics

Table 1. Descriptive Statistics for Outsider-Controlled (Compliant) Boards in Year 2000

\begin{tabular}{lcccccc}
\hline \multicolumn{1}{c}{ Variable } & Firms & Obs. & Mean & Std. Dev. & Minimum & Maximum \\
\hline Operating Return on Assets & 268 & 3506 & 13.09429 & 11.95929 & -166.6316 & 38.69322 \\
Tobin's Q & 268 & 3506 & 2.3501 & 1.767683 & .7519326 & 9.21591 \\
Book-Leverage Ratio & 268 & 3506 & 17.2265 & 19.68479 & 0 & 94.36789 \\
Market-to-Book-Ratio & 268 & 3506 & 3.485075 & 3.915067 & -8.769362 & 22.53574 \\
Total Assets & 268 & 3506 & 7008.622 & 21851.66 & 19.474 & 247816 \\
\hline
\end{tabular}

The descriptive statistics for outsider-controlled firms are displayed in Table 1. Of the total 381 firms, 268 firms (70\%) had an average operating return on assets of $13.09 \%$, an average Tobin's Q of 2.35 , an average book-leverage ratio of $17.23 \%$, an average market-to-book-ratio of 3.49 , and average total assets of $\$ 7.0$ billion.

Table 2. Descriptive Statistics for Insider-Controlled (Noncompliant) Boards in Year 2000

\begin{tabular}{lcccccc}
\hline \multicolumn{1}{c}{ Variable } & Firms & Obs. & Mean & Std. Dev. & Minimum & Maximum \\
\hline Operating Return on Assets & 113 & 1499 & 15.44547 & 10.4257 & -96.11204 & 38.69322 \\
Tobin's Q & 113 & 1499 & 2.3987 & 1.733685 & .7519326 & 9.21591 \\
Book-Leverage Ratio & 113 & 1499 & 14.40096 & 18.59812 & 0 & 94.36789 \\
Market-to-Book Ratio & 113 & 1499 & 3.390375 & 3.834543 & -8.769362 & 22.53574 \\
Total Assets & 113 & 1499 & 5179.308 & 26414.04 & 42.593 & 247816 \\
\hline
\end{tabular}

The descriptive statistics for the other 113 firms (30\%) are displayed in Table 2. Noncompliant firms had an average operating return on assets of $15.45 \%$, an average Tobin's Q of 2.4, an average book-leverage ratio of $14.40 \%$, an average market-to-book-ratio of 3.39 , and average total assets of $\$ 5.2$ billion.

Table 3. Full Sample Descriptive Statistics for Year 2000

\begin{tabular}{lccccc}
\hline \multicolumn{1}{c}{ Variable } & Firms & Observations & Mean & $\mathrm{t}$ & $\mathrm{P}$ \\
\hline Operating Return on Assets & 381 & 5005 & 13.7985 & -2.3382 & 0.0199 \\
Tobin's Q & 381 & 5005 & 2.3646 & -0.3373 & 0.7361 \\
Book-Leverage Ratio & 381 & 5005 & 16.3803 & 1.5325 & 0.1262 \\
Market-to-Book-Ratio & 381 & 5005 & 3.4567 & .3601 & 0.7198 \\
Total Assets & 381 & 5005 & 6460.74 & 0.7294 & 0.4662 \\
\hline
\end{tabular}

Table 3 provides the descriptive statistics for the full sample of 381 publicly traded firms and 5,005 unique annual observations. The sample firms had an average operating return on assets of $13.80 \%$, an average Tobin's $\mathrm{Q}$ of 2.36, an average book-leverage ratio of $16.38 \%$, an average market-to-book-ratio of 3.46, and average total assets of $\$ 6.5$ billion.

Table 3 also shows the t-value and P-value for comparing the outsider-controlled and insider-controlled firms. On average, outsider-controlled firms experienced a lower operating return on assets than insidercontrolled firms but the difference was not statistically significant. Additionally, outsider-controlled firms experienced a higher market-based return on assets, more book leverage, a higher market-to-book-ratio, and were larger as measured by total assets than insider-controlled firms; but these outcomes were not significant.

\subsection{Multiple Regression}

Table 4. Multiple Regression using Operating Return on Assets as the Dependent Variable

\begin{tabular}{lcccccc}
\hline \multicolumn{1}{c}{ Variable } & Firms & Obs. & Coefficient & Std. Error & $\mathrm{t}$ & $\mathrm{P}$ \\
\hline Inside Board*Post Regulation & 381 & 5005 & .4969899 & .8908285 & 0.56 & 0.577 \\
$\ln$ (Book-Leverage Ratio) & 381 & 5005 & -1.075103 & .2537484 & -4.24 & 0.000 \\
$\ln$ (Market-to-Book-Ratio) & 381 & 5005 & 4.705699 & .6859133 & 6.86 & 0.000 \\
$\ln$ (Total Assets) & 381 & 5005 & 1.576092 & .4134389 & 3.81 & 0.000 \\
\hline
\end{tabular}

Table 4 depicts the multiple regression analyses of the effects of the changes in NASDAQ rules on firm performance during the period 1997-2012 using difference-in-difference estimates. $\mathrm{R}^{2}$ for the model is $61.85 \%$. The interactive coefficient for Inside Board*Post Regulation (0.497) is positive but not significant, suggesting that noncompliant firms did not experience an increase in performance due to the mandated changes in NASDAQ rules over the long run.

Of the control variables, Book Leverage Ratio shows a negative association with firm performance in contrast to Market-to-Book Ratio and Total Assets, which each have a positive association with firm performance. Overall, the results described in Table 4 do not support the conventional point of view that strengthened corporate-governance measures improve firm performance.

\subsection{Tobin's $Q$}

We used Tobin's $\mathrm{Q}$ as an alternative measure for firm performance. The market-based measure is forward looking but reflects current decisions (Al-Matari, Al-Swidi, \& Fadzil, 2014). We calculated Tobin's Q as the 
ratio of the difference between market capitalization (market value of outstanding shares) of the firm and the book value of debt divided by the book value of total assets. This can be considered a measure of how well firms used their assets to provide returns to shareholders. A value of less than 1 is an indication that the firm did not use assets well and that the firm is inefficient. A number greater than 1 indicates that the firm used its assets efficiently to create value.

The mean values for Tobins's Q are presented in Tables 1-3. In table 1, the mean for compliant firms is 2.35 , indicating a favorable return on assets and a favorable firm value for companies with outsider-controlled boards. In table 2, the mean for noncompliant firms is 2.40 , also indicating a favorable return on assets and a favorable firm value for companies with insider-controlled boards. In table 3 , the mean for the full sample result is $2.36, \mathrm{t}$ $=-0.34$, and $\mathrm{P}=0.74$, indicating that the changes in corporate-governance mechanisms had a slightly negative and nonsignificant impact on the performance of firms that were previously insider-controlled.

Table 5. Multiple Regression using Tobin's $Q$ as the Alternative Dependent Variable

\begin{tabular}{lcccccc}
\hline \multicolumn{1}{c}{ Variable } & Firms & Obs. & Coefficient & Std. Error & $\mathrm{t}$ & $\mathrm{P}$ \\
\hline Inside Board*Post Regulation & 381 & 5005 & .0377832 & .092523 & 0.41 & 0.683 \\
In (Book-Leverage Ratio) & 381 & 5005 & -.2509789 & .0213455 & -11.76 & 0.000 \\
In (Market-to-Book-Ratio) & 381 & 5005 & 2.273066 & .1100256 & 20.66 & 0.000 \\
ln (Total Assets) & 381 & 5005 & -.0798769 & .0290856 & -2.75 & 0.006 \\
\hline
\end{tabular}

To further validate our discovery, we repeated the DD analysis using market-based return on assets (Tobins's Q) as an alternative measure for firm performance. The result of the DD test is presented in Table 5. $\mathrm{R}^{2}$ for the model is $83.00 \%$. As expected, the $\mathrm{DD}$ variable produced a small coefficient (.04) that is not statistically significant $(\mathrm{t}=0.41, \mathrm{P}=0.68)$. Similar to $\mathrm{OROA}$, the results indicate that non-compliant firms listed on NASDAQ were not materially affected by the strengthened monitoring and oversight rules as measured by Tobin's Q.

Of the control variables, Book Leverage Ratio and Total Assets each show a negative association with firm performance in contrast to Market-to-Book Ratio, which has a positive association with firm performance. Overall, the results described in Table 5 do not support the conventional point of view that strengthened corporate-governance measures improve firm performance.

\section{Conclusion}

The results in Tables 1-5 indicate that strengthened corporate-governance measures had little or no impact on the long-run performance of U.S. firms listed on NASDAQ. Our contribution to the literature is finding that the strengthened corporate-governance measures did not significantly impact firms listed with NASDAQ over an extended period of time, specifically 10 years.

Our study is consistent with the window-dressing view, which asserts that managers retain their influence over the board of directors and avoid the monitoring effects of the new corporate-governance rules. Under this view, strengthened corporate governance has no effect on firm performance (Duchin et al., 2010). Duchin et al. (2010) suggested that a CEO might ask a close friend to serve on the board who was technically qualified but not likely to challenge his friend. Managers could select board members that technically meet required guidelines but are sympathetic to management, giving only the appearance that things have changed (Romano, 2005; Duchin et al., 2010).

Regulators adopted similar rules for NYSE and NASDAQ, but the rules were not identical. Firms listed with NYSE were required to have auditing, compensation, and nominating committees that were composed entirely of independent directors. Firms listed with NASDAQ were required to have an audit committee comprised entirely of independent directors, but they were not required to form compensation and nominating committees until 2012. More research is needed to determine if these differences, though small, had a significant effect on firm performance across both trading platforms. We also recommend further research related to crosslisted firms located outside the United States. More research is needed to determine if cross-listed firms were affected the same way as U.S. firms.

\section{References}

Agarwal, S., Goel, R., \& Vashishtha, P. K. (2014). A literature review of agency theory. Indian Journal of Research, $2(5)$, https://www.worldwidejournals.com/paripex/recent_issues_pdf/2014/May/May_2014_1400155059_f3d33_ 17.pdf

Al-Matari, E., Al-Swidi, A., \& Hanim, F. (2014). The measurements of firm performance's dimensions. Asian Journal of Finance \& Accounting, 6(24). https://doi.org/10.5296/ajfa.v6i1.4761.

Bebchuk, L. A., \& Fried, J. M. (2005). Pay without performance: Overview of the issues. Journal of applied corporate finance, 17(4), http://www.law.harvard.edu/programs/olin_center/papers/pdf/Bebchuk_et\%20al_528.pdf 
Bhagat, S., \& Black, B., (2002). The non-correlation between board independence and long-term firm performance. The Journal of Corporation Law, 27, 231-273. https://ssrn.com/abstract=133808

Bhagat, S., \& Bolton, B. J. (2008). Corporate governance and firm performance. Journal of Corporate Finance, 14(3), 257-273. https://doi.org/10.1016/j.jcorpfin.2008.03.006

Chen, X., Cheng, Q., \& Wang, X. (2011). Does increased board independence reduce earnings management? Review of Accounting Studies, 20(2). https://doi.org/10.1007/s11142-015-9316-0

Cheng, S. (2008) Board size and the variability of corporate performance. Journal of Financial Economics, 87, 157-176. https://doi.org/10.1016/j.jfineco.2006.10.006

Chhaochharia, V., \& Grinstein, Y. (2007). Corporate governance and firm value: The impact of the 2002 governance rules. The Journal of Finance, 62(4), 1789-1825. https://ssrn.com/abstract=556990

Coles, J. L., Daniel, N. D., \& Naveen, L. (2008). Boards: Does one size fit all? Journal of Financial Economics, 87, 329-356. https://doi.org/10.1016/j.jfineco.2006.08.008

Duchin, R., Matsusaka, J. G., \& Ozbas, O. (2008). When are outside directors effective? Journal of Financial Economics, $96(2)$

195-214. https://citeseerx.ist.psu.edu/viewdoc/download?doi=10.1.1.433.8955\&rep=rep1\&type=pdf

Faleye, O., Hoitash, R., \& Hoitash, U. (2011). The costs of intense board monitoring. Journal of Financial Economics, 101(1), 160-181. https://doi.org/10.1016/j.jfineco.2011.02.010

Fama, E. F., and Jensen, M. C. (1983). Agency problems and residual claims. Journal of law and Economics 26(2), 327-349. https://dx.doi.org/10.2139/ssrn.94032

Gordon, J.N. (2007). The rise of independent directors in the United States, 1950-2005: Of shareholder value and stock market prices. Stanford Law Review, 59(6), 1465-1568. https://ssrn.com/abstract=928100

Guo, L., Lach, P., \& Mobbs, S. (2015). Tradeoffs between internal and external governance: evidence from exogenous regulatory shocks. Financial Management, 44(1), 81-114. https://www.jstor.org/stable/24736484

Hermalin, B. E., \& Weisbach, M. S. (1991). The effects of board composition and direct incentives on firm performance. Financial Management, 20(4), 101-112. https://www.jstor.org/stable/3665716

Jensen, M. C., \& Meckling, W. H. (1976). Agency costs and the theory of the firm. Journal of Financial Economics, 3(4), 305-360. https://doi.org/10.1016/0304-405X(76)90026-X

Linck, J. S., Netter, J. M., \& Yang, T. Y. (2008). The determinants of board structure. Journal of Financial Economics, 87, 308-328. https://doi.org/10.1016/j.jfineco.2007.03.004

Mitnick, B. (2019). Origin of the theory of agency: An account by one of the theory's originators. SSRN Electronic Journal. https://doi.org/10.2139/ssrn.1020378.

Pandya, D., \& Bathala, C. (2013). Board of directors and exchange requirements: Operating performance of traditionally insider controlled boards. Journal of Applied Financial Research, 1, 88-102. https://ssrn.com/abstract $=2685323$

Pandya, D., \& Van Deventer, I. A. (2021). The Effect of Strengthened Corporate Governance on Firm Performance in the United States. Journal of Accounting, Business and Finance Research, 12(2), 26-31. https://doi.org/https://doi.org/10.20448/2002.122.26.31

Romano, R., (2005). The Sarbanes-Oxley Act and the making of quack corporate governance. Yale Law Review, 114, 1521-1611. https://ssrn.com/abstract $=596101$

Wang, C., Xie, F., \& Zhu, M. (2015). Industry expertise of independent directors and board monitoring. Journal of Financial and Quantitative Analysis, 50(5), 929-962. https://doi.org/10.1017/S0022109015000459

Zogning, F. (2017). Agency theory: A critical review. European Journal of Business and Management, $9(2), 1-8$. https://www.iiste.org/Journals/index.php/EJBM/article/viewFile/34900/35901 